\title{
Moleküler Kimerizm Metotlar1: Geçmiş ve Günümüz
}

\section{Molecular Chimerism Methods: Past and Present}

\author{
Figen ABATAY SEL, Fatma SAVRAN OĞUZ
}

İstanbul Üniversitesi, İstanbul Tıp Fakültesi, Tıbbi Biyoloji Anabilim Dalı, İstanbul, Türkiye

Yazıșma Adresi

Correspondence Address

Figen ABATAY SEL

İstanbul Üniversitesi

İstanbul Tıp Fakültesi,

Tibbi Biyoloji

Anabilim Dalı, İstanbul, Türkiye

figen.abatay@gmail.com

Geliş tarihi / Received : Şubat 10, 2021 Kabul tarihi / Accepted : Mart 12, 2021 Elektronik yayın tarihi : Ocak 01, 2022 Online published

Bu makalede yapılacak atıf:

Cite this article as:

Abatay Sel F, Savran Oğuz F.

Moleküler kimerizm metotları:

Geçmiş ve günümüz.

Akd Tip D 2022; 8(1):82-90.

Figen ABATAY SEL

ORCID 0000-0002-1155-1284

Fatma SAVRAN OĞUZ

ORCID 0000-0002-6018-8936

\section{öz}

Kimerizm analizi, hematolojide allojenik hematopoetik kök hücre transplantasyonu (AHKHT) sonrası hastadaki donör hücre miktarının tespiti için kullanılan bir tanı yöntemidir. Transplantasyon sonrası yapılan kimerizm analizi, donör hücre engraftmanı ve hastalığın relapsı açısından oldukça önemli bilgiler vermektedir. Kimerizm analizi, çeşitli belirteçler ve teknikler kullanılarak yapılmaktadır. Son zamanlarda kantitatif-gerçek zamanlı polimeraz zincir reaksiyonu (qRT-PCR), dijital droplet-PCR (dd-PCR) ve yeni nesil dizileme (NGS) gibi yeni kimerizm yöntemleri kullanılmaktadır. Bu derlemede multipleks kısa ardıșık tekrarlı dizi tabanlı PCR (STR-PCR) yöntemi ile yeni moleküler qRT-PCR, dd-PCR ve NGS yöntemlerinin avantajlı ve dezavantajlı yönleri karşıllaştırılıp tartışılmıştır.

Anahtar Sözcükler: Kimerizm analizi, STR-PCR, qRT-PCR, dd-PCR, NGS

\section{ABSTRACT}

Chimerism analysis is a diagnostic method used to determine the amount of donor cells in the patient for hematologic cases after allogeneic hematopoietic stem cell transplantation (AHSCT). Post-transplant chimerism analysis provides very important information in terms of donor cell engraftment and relapse. Chimerism analysis is performed using various markers and techniques. Recently, new chimerism methods have been used such as quantitative-real time polymerase chain reaction (qRT-PCR), digital droplet-PCR (dd-PCR) and next generation sequencing (NGS). In this review, multiplex short tandem repeat based-PCR (STR-PCR) and new molecular methods qRT-PCR, dd-PCR and NGS were compared and discussed in the terms of advantageous and disadvantageous aspects.

Key Words: Chimerism analysis, STR-PCR, qRT-PCR, dd-PCR, NGS

\section{Kimerizm Tanımı}

Kimerizm terimi, birçok sanat eserinde kullanılan ve mitolojide kanatlı bir at olarak tasvir edilen Pegasus'un üzerine binmiş "Bellerophon" ile mücadelesiyle tanınan "Kimera" adlı yaratıktan gelir (1) (Şekil-1). "Homeros’un İlyada" eserinde aslan başlı, keçi gövdeli, yılan kuyruklu ve alev soluyan bir yaratık olarak tasvir edilmektedir. Dünyanın birçok müzesinde, farklı kültürlerde kimera eserlerine rastlanılmaktadır (1).

Tıp literatüründe kimerizm, farklı zigottan köken almış farklı genetik içeriğe sahip birden fazla hücre setinin bir arada bulunması durumudur $(2,3)$. Bireylerde kimerizm, hamilelik sırasında fetal hücrelerin anne kanına karıșması ve hamileliğin morula evresinde iki fertilize olmuş yumurta hücresinin kaynaşması ile spontane olarak gelişebilmektedir (2-4). Bu tip kimerizm gelişimi adli tıp alanının konusu olup ilgi çekici birçok davanın çözümlenmesinde kimerizm vakaları yer almaktadır (5-7). Ayrıca kimerizm analizleri ana-babalık tayini gibi adli vakalar için kullanılmaktadır (8-10). Dışarıdan bir müdahale sonrasında da kimerizm gerçekleşebilmektedir. Müdahale sonucu kimerizm, allojenik doku ve organ transplantasyonu sonrasında gelişebildiği gibi, biyomühendislik alanına giren ve birçok deneysel tedaviye öncülük etmiş olan rekombinant tekniklerin kullanımı sonrasında da gelişebilmektedir (11). 


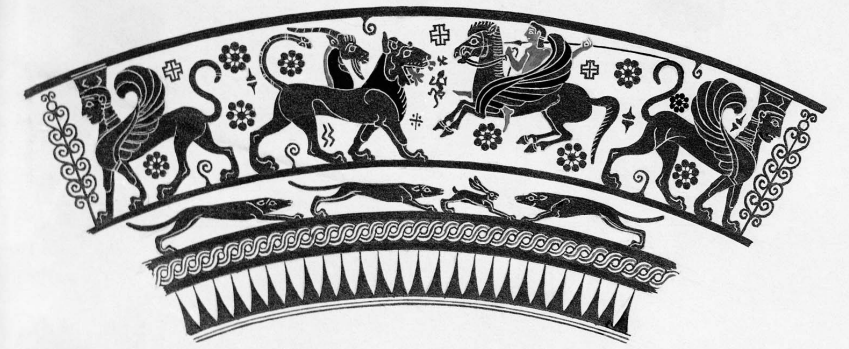

Hematolojide Kimerizm

Allojenik hücre tedavileri çok çeşitli hastalık ve rahatsızlıklar için kullanılan bir tedavi yöntemidir. Örneğin kardiyak hastalıklarda, son dönem böbrek yetmezliğinde, çeşitli organ hastalıklarında “Allojenik Kök Hücre Tedavileri” kullanılmaktadır (12-14). Hematolojik hastalıkların allojenik hematopoetik kök hücre transplantasyonu (AHKHT) sonrası uzun süreli izleminde tedavi başarısı birçok faktöre bağlıdır. $\mathrm{Bu}$ faktörler; hastaya uygun hazırlık rejimi (hastanın tüm lösemik hücrelerinin yok edilmesinin hedeflendiği stratejik ilaç/terapi seçimi), donör yaşı (daha genç olan donöre ait $\mathrm{T}$ hücrelerinin lösemik hücreleri yok etmede daha başarılı oluşu), hastanın AHKHT anındaki durumu (aktif hastalık, hastalığın relaps durumu) ve greft başarısıdır (transplanta-
Şekil-1:

Pegasus üzerindeki Bellephoron ve Kimera figürü Boston 400 olarak adlandırılmış kimera figürü desenli Yunan vazosu New York Güzel Sanatlar Müzesi'nde sergilenmektedir ve M.Ö. 650 y1lında yapılmış olduğu kabul görülmektedir.

syon sonrası oluşan greftin lösemi hücrelerini manipüle etme gücü).

Hastanın kimerizm durumu, transplantasyon başarısını etkileyen en önemli faktörlerden biridir. Hematopoetik kök hücrelerin engraftman başarısı "Tam Kimerizm" olma dinamiğine bağlıdır. AHKHT sonrası yapılan kimerizm sonucuna göre hastanın hematopoezinin tamamen ya da $>$ \%95 donörden gelen hematopoetik kök hücrelerden oluştuğunu gösteren kimerizm analizi sonucu "Tam Kimerizm" olarak adlandirılır ve bu durum transplantasyon başarısı ile ilişkilidir. Diğer yandan transplantasyon sonrası hematopoezin \%95'in altına düştüğü ve hem donörün hem de hastanın hücrelerinden oluşan duruma ise "Karışık Kimerizm" adı verilmektedir (Şekil-2).

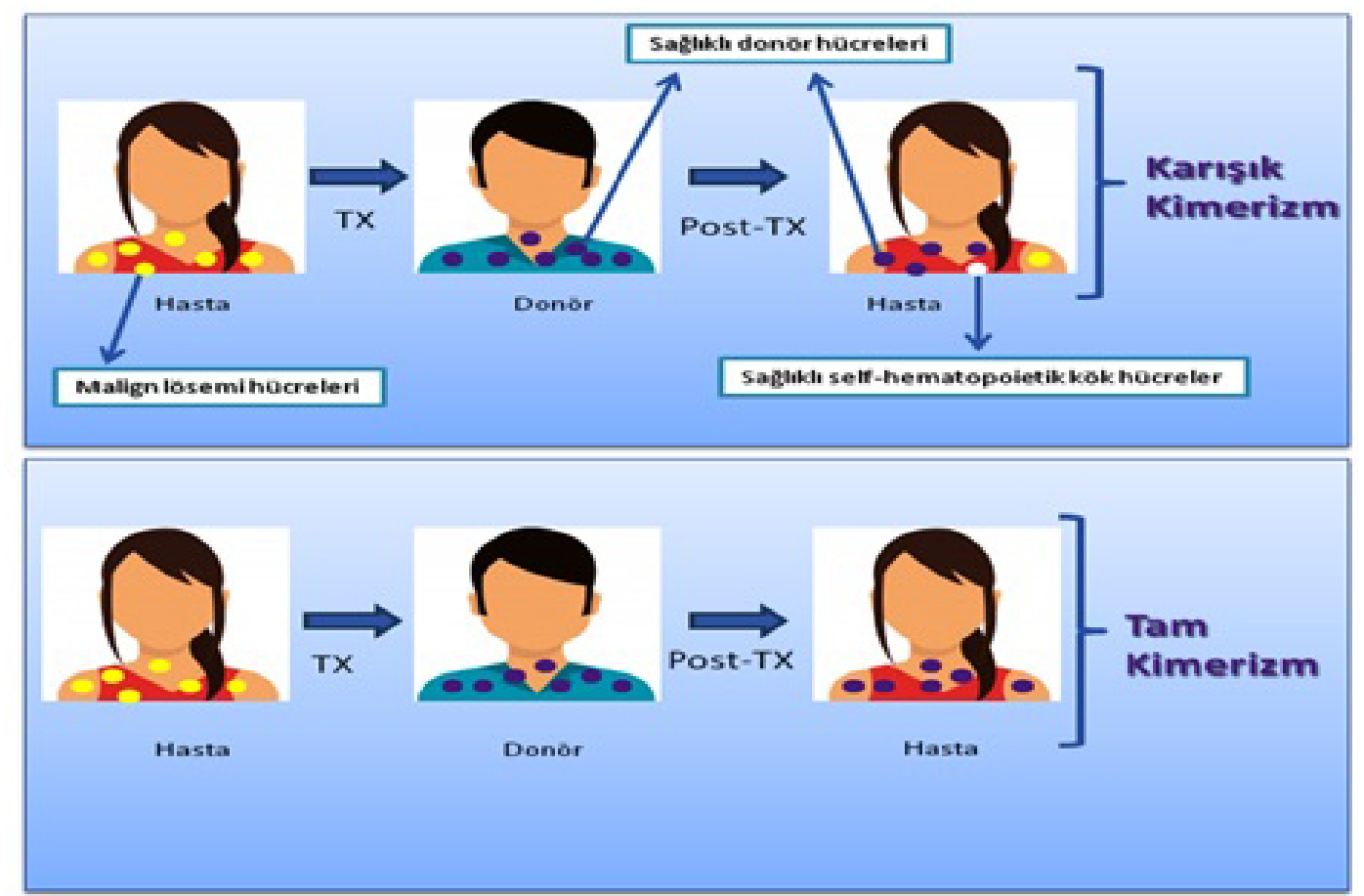

Şekil-2:

Hematolojide Tam ve Karışık Kimerizm Lösemik hücreler sarı, sağlıklı donör hücreleri mor, sağlıklı hasta hücresi ise beyaz renkli olarak gösterilmiştir. TX:Transplantasyon, Post-TX: Transplantasyon sonrası

Karışık kimerizm, yeniden tam kimerizme dönebileceği gibi, artan ve stabil karışık kimerizm olarak da seyredebilir. Split ve mikrokimerizm terimleri de sıklıkla yer alan kavramlardır. "Split kimerizm" transplantasyon sonrası gelişen dinamiklerden biridir. Transplantasyon sonrası hastada bir lenfosit hücre alt grubunun donörden, diğer bir lenfosit hücre alt grubunun ise hastadan kaynaklı olma durumudur. Ayrıca total DNA'nın kullanıldığ 1 hasta örneklerinde tam kimerizm çıkarken, lenfosit alt gruplarında durum bunun aksine karışık kimerizm şeklinde gözlenebilmektedir. "Mikrokimerizm" terimi ise $\% 0,1-0,3$ oranında donöre ait hücrelerin hastada görülme durumudur. Birden fazla doğumu olan annelerde, cinsiyet uyumsuz kan transfüzyonları sonucunda ve solid organ transplantasyonu sonrası donör lenfositlerinin neden olduğu kimerizm durumunu anlatmak için kullanılan bir terimdir (15-17). Tablo-I'de kimerizm çeşitleri ile tanımlamaları verilmiştir. 
Tablo-I: Kimerizm çeşitleri

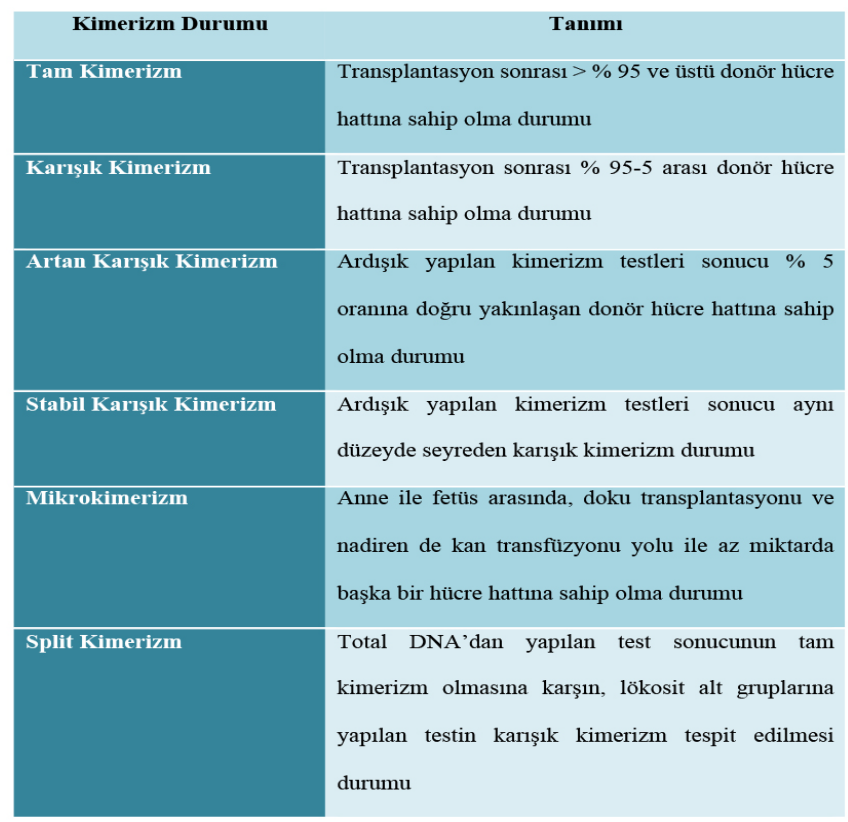

Transplantasyon Başarısını Etkileyen

\section{Kimerizm Analizi Dinamikleri}

Tüm transplantasyon hekimlerinin birincil amacı transplantasyon sonrasında hastada tam bir remisyon elde edip yaşam süresini uzatmaktır ve bu durum transplantasyon sonrasi hastanın uzun süreli takibine bağlıdır. Bu takip, kimerizm izlemi ile yapılmaktadır ve izlemin hangi zamanlarda yapılacağının önemli olduğunu gösteren çalışmalar mevcuttur (18). Transplantasyon sonrasi +30 ., +60 . ve +100 . günlerde kimerizm analizi değerlendirme açısından önemli süreçler olduğu, ayrıca 6., 9., 12., 15. ve 18. aylarda yapılan izlemin, transplantasyonun başarı seyrini değiştirdiği öne sürülmektedir (19). Transplantasyon başarısını olumsuz yönde etkileyen artan karışık kimerizm vakalarının, düşük doz donör lenfosit infüzyonu ve transplantasyon öncesi alınan immünsüpresyonların transplantasyonun hemen ardından devam edilmemesi sebebiyle oluştuğu düşünülmektedir $(18,20)$.

Kimerizm analizinin hassaslığını etkileyen önemli faktörlerden biri de, hastadan alınacak olan kan örneğinin kökenidir (21). Rutin kimerizm analizleri için periferal kan kök hücreleri yerine kemik iliğinden alınan numunelerin daha hassas sonuçlar verdiği ve periferal kandan alınan örneklerden elde edilmiş olan tam kimerizm sonuçlarının dikkatle yorumlanması tavsiye edilmektedir $(21,22)$.

Transplantasyon başarısının etkileyen dinamikler arasında kimerizm izleminde kullanılacak yöntemin seçilmesi de bulunmaktadır. Kimerizm izleminde birçok yöntem mevcuttur. Eritrosit fenotiplemesi, Fluoresans In Situ Hibridizasyon (FISH) ve DNA polimorfizmine dayanan PCR yöntemleri kimerizm için geçmişten günümüze kadar kullanılan yöntemler arasında yer almaktadır. Cinsiyet-uyumsuz transplantasyonlarda FISH tekniği tercih edilebilmektedir. FISH tekniğinde diğer tekniklerden farklı olarak donörün DNA'sına gerek kalmadan çalışma yapılabilmektedir. FISH ve eritrosit fenotiplemesi yöntemleri uzun sürmesinin yanı sıra duyarlılık açısından düşük kalmaktadır. Kimerizm analizi için, multipleks STR-PCR yöntemi altın standart yöntem olarak kabul edilmektedir. Son dönemlerde PCR tabanlı farklı moleküler yöntemler ve farklı duyarlılıklara sahip metotlar geliştirilmiştir. Tablo-II'de moleküler kimerizm yöntemleri avantaj ve dezavantajlarıyla belirtilmiştir.

Tablo-II: Moleküler kimerizm yöntemlerinin karşılaştırılması

\begin{tabular}{|c|c|c|c|}
\hline Yöntem & $\begin{array}{c}\text { Kısıtlilığı } \\
(\%)\end{array}$ & Avantaj & Dezavantaj \\
\hline RFLP & $1-10$ & Semi-kantitatif & $\begin{array}{l}\text { Uzun sürede sonuç } \\
\text { raporlama ve tekniğin } \\
\text { uygulamasının zor oluşu }\end{array}$ \\
\hline VNTR & $1-5$ & Semi-kantitatif & $\begin{array}{c}\text { Uzun sürede sonuç } \\
\text { raporlama }\end{array}$ \\
\hline STR & $1-3$ & $\begin{array}{l}\text { Semi-kantitatif, multipleks } \\
\text { sistemde } 3 \text { iş gününde sonuç } \\
\text { raporlayabilme }\end{array}$ & $\begin{array}{c}\text { Erken dönem karışık } \\
\text { kimerizmi yakalamak için } \\
\text { sık aralıklarla test izlemine } \\
\text { gerek duyulması }\end{array}$ \\
\hline qRT-PCR & 0,1 & $\begin{array}{c}\text { Kantitatif, DNA izolasyon } \\
\text { işlemiyle } 3 \text { saatte sonuç } \\
\text { raporlayabilme }\end{array}$ & $\begin{array}{c}\text { Kimerizm izlemi için } \\
\text { birden fazla (en az 3) } \\
\text { informatif belirtece ihtiyaç } \\
\text { duyulması }\end{array}$ \\
\hline dd-PCR & $\begin{array}{c}\text { Tekrar } \\
\text { edilebilir } \\
\text { bir yöntem }\end{array}$ & $\begin{array}{c}\text { Kantitatif, } \\
\text { standart eğriye ihtiyaç duyma, } \\
45 \text { dakikada sonuç } \\
\text { raporlayabilme }\end{array}$ & $\begin{array}{c}\text { Maliyet yüksekliği, } \\
\text { kimerizm izlemi için } \\
\text { birden fazla informatif } \\
\text { belirtece ihtiyaç duyulmas }\end{array}$ \\
\hline NGS & 0,001 & $\begin{array}{c}\text { Kantitatif, tek bir tüpte } \\
\text { çalışabilme avantajı, } 5 \text { saatte } \\
\text { sonuç raporlayabilme }\end{array}$ & $\begin{array}{l}\text { Maliyet yüksekliği, test ve } \\
\text { analizinin kompleksliği ve } \\
\text { biyoinformatik bilgilerin } \\
\text { doğru yorumlanabilmesi }\end{array}$ \\
\hline
\end{tabular}

\section{KIMERIZM ANALIZINDE KULLANILAN MOLEKÜLER YÖNTEMLER}

Restriksiyon Parça Uzunluk Polimorfizmi

Restriksiyon parça uzunluk polimorfizmi (RFLP) metodolojisi genomik DNA'nın restriksiyon endonükleaz aktivitesi ile farklı uzunluklarda kesimiyle ilişkilidir (23). Bu yöntem, kişiden kişiye farklı sayıda tekrar eden ve bu nedenle değişen uzunluklarda oluşan restriksiyon bölgelerinin hibridizasyon problarıyla ayrımına dayanan bir yöntem olarak tanımlanabilir. Tüm restriksiyon parçaları southern blotting tekniği ile jelden membrana DNA parçaları transfer edilir ve büyüklükler buradan tespit edilir. RFLP metodunda dikkat edilmesi gereken bir diğer önemli nokta, genomik DNA'nın konsantrasyonudur. Bu yöntemde gerek işlemlerin uzunluğu gerekse testin doğru çıkması için gereken DNA miktarının fazlalığı bu yöntemin uygulanabilirliği önündeki engeller arasında sayılmaktadır.

\section{Minisatellitler: Değişken Sayılı}

\section{Ardişık Tekrarlar}

Laboratuvarlarda PCR yönteminin kullanılmaya başlanması ile birlikte spesifik sekansların komplementerleri olan primerler aracılığıyla çeşitli bölgelerin amplifikasyonu gerçekleştirilerek RFLP yöntemine göre daha kolay yöntem- 
ler geliştirilmiştir. Bunlardan biri DNA'nın ardışık tekrarlı bölgelerinin kullanılmasına dayanmaktadır ve bu bölgeler kimerizm metodu için sıklıkla kullanılan genom bölgeleridir. $\mathrm{Bu}$ ardışık tekrarlı bölgelere "satellit" adı verilir ve genomda bulunduğu bölge, uzunluk ve baz çiftlerinin tekrarlarına göre üçe ayrilmaktadırlar:

1. Makrosatellit

2. Mikrosatellit

3. Minisatellit

Satellitler DNA'nın 1000-100.000 tekrarları içeren bölgeleridir.

Makrosatellitler genomun büyük bir bölümünde, kromozomların sentromer ve telomer bölgelerinde bulunur. Genellikle $\mathrm{CpG}$ adacıklarından zengin olan makrosatellitler

kromatin organizasyonunda yapısal ve düzenleyici bir role sahip olduğu kabul edilmektedir (24).

Tüm satellit bölgeler 100 milyon baz çifti uzunluğunda, heterokromatin bölgeler içermektedir. Kimerizm analizinde mikrosatellitler ve minisatellitlerin özelliklerinden faydalanılarak PCR tabanlı laboratuvar teknikleri geliştirilmiştir.

Minisatellitler 9-100 baz çiftlik tekrarlarla 500-30.000 baz çifti uzunluğunda olan ve genellikle ökromatin bölgede yer alan ardışık tekrarlı bölgelerdir. Minisatellitler, değişken sayılı ardışık tekrarlar (VNTR) olarak bilinmektedir. VNTR yöntemi, uzun sürede sonuç vermesi ve hassasiyetinin düşük olması nedeniyle günümüzde tercih edilen bir yöntem değildir. Ayrıca kantitatif bir değerlendirme olanak sağlayamaması ve diğer yöntemlere kıyasla çok daha fazla DNA konsantrasyon ve miktarının gerekliliğinden dolayı bu yöntem tercih edilmemektedir.

Mikrosatellitler: Kısa Ardışık Sayılı Tekrarlar Mikrosatellitler genomun her yerine dağılmış durumda olan tekrarlı bölgelerdir. Kısa Ardışık Tekrarlar (STR) olarak adlandırılırlar. Bu tekrar bölgeleri 2-6 baz çiftinin ardışık tekrarından oluşmakta olup genomda 10.000-100.000 baz çiftlik bir uzunluğa sahiptirler. VNTR ile karşılaştırıldığında ardışık tekrar uzunluğu daha fazla olmasına karşın daha küçük birimler oluşturmaktadır. Tek nükleotid polimorfizmleri (SNP), RFLP, VNTR ve STR'lar genomda farklı bölgelerde, farklı uzunluklarda bulunup farklı ayırım gücüne sahiptirler (Şekil-3) (25).

Kapiller elektroforeziyle çalışan ve 96 kuyucuklu plate'in tek bir kuyucuğunda hastanın birden fazla lokusa ait ayırt edici bilgileri veren multipleks STR-PCR yöntemi, kimerizm analizi için altın standart yöntem olarak kabul edilmektedir $(26,27)$. Bu yöntem ile bilgilendirici (informatif) lokus ayrımı; farklı boylardaki moleküler belirteçler ve farklı renklerdeki primerler aracılığıyla sağlanabilmektedir. Bir diğer önemli avantajı ise az miktarda hücreden elde edilen DNA ile kolay bir şekilde kimerizm izlemi yapılabilmesine olanak sağlamasıdır. İnformatif lokusların seçimi ve sonrasında bu lokuslar üzerinden yapılan izlem ile manuel bir veri analizi yapılmasını gerektirir ve bu durum zaman alıcıdır. Bu yöntemle analiz sonucu iki ya da üç iş günü içinde verilebilmektedir. Karışık Kimerizm saptanması durumunda Thiede ve arkadaşlarının 1999 yılında yayınlamış oldukları denklem ile analiz yazılımındaki informatif lokuslara ait alanlardan kantitatif bir değer hesaplanabilmektedir (28). Semi-kantitatif bir analiz sonucu verilmesi insan hatalarına karşı açık kılabilmektedir. Buna karşılık R tabanlı programlama ile yazılmış ve ücretsiz erişim sunulan RChimerism program1, STR-PCR yöntemini hem kantitatif hale dönüşmesine hem de analizin daha kısa sürede gerçekleşmesine sebep olacağı öne sürülmüştür (29). Ayrıca RChimerism ile çift donörlü kordon kanı transplantasyonu sonrası oluşan hematopoezden her iki donöre ait hücrelerin yüzdesinin verilebileceğini belirtmişlerdir.

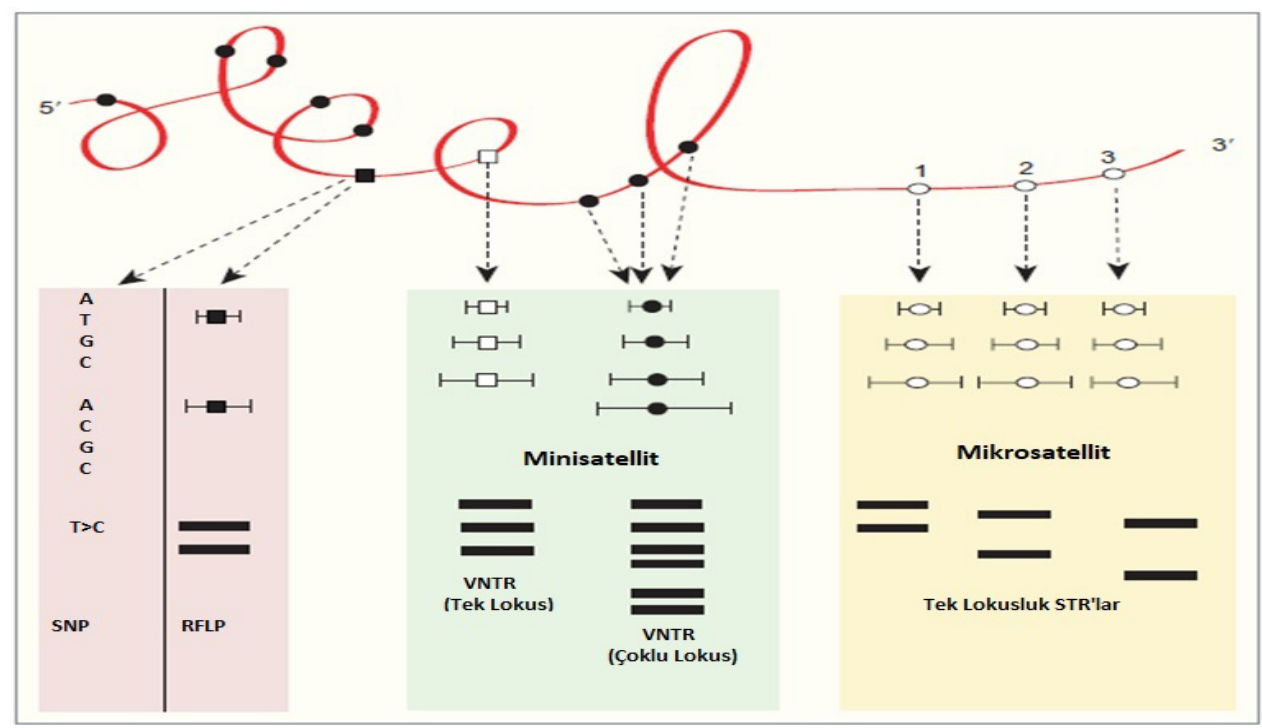

Şekil-3: Kimerizm Yönteminde Kullanılan DNA Polimorfizmleri Polimorfizm populasyonda \% 1'in üzerinde bulunan çeşitli DNA sekanslarındaki değişim olarak tanımlanmaktadır. Bu değişimler DNA sekansındaki tek bir nükleotidin değişikliği olabileceği gibi, sekansların uzunlukları ve tekrarlarını kapsayan bölgeler şeklinde de olabilir. a:RFLP ve SNP'leri göstermektedir. Bu şekilde sol tarafta, RFLP tek bir lokusta bulunan ve sabit boyutlu iki polimorfik bant üretmektedir. SNP ise bu restriksiyon alanındaki tek bir baz çiftinin değişikliğini göstermektedir (T>C), $\square$ : işareti ise tek bir lokustaki VNTR bantlarını göstermektedir. Bu polimorfizmler RFLP'lere göre daha informatiftir, •: Farklı tek lokus VNTR'larının birleşimi (Çoklu VNTR) gösterilmiş olup bu tip polimorfizm ise bireyler bazında değerlendirilme yapıldığında çok daha karakteristik ve ayrıntılı bilgi verebilmektedir, o: Mikro satellitler gösterilmektedir. Her bir STR, tek lokustaki VNTR gibi farklı bir profil oluşturur. PCR ile multipleks çalışıldığında ise VNTR'lara göre oldukça yüksek ayırım gücüne sahiptir. 


\section{Kantitatif Gerçek Zamanlı PGR}

Günümüzden 25 yıl kadar önce, moleküler diyagnoz ve araştırma yöntemlerinde PCR kullanımı sonrasında, geleneksel PCR'a göre daha hızlı, hassas ve kolay olan kantitatif gerçek zamanlı PCR (qRT-PCR) olarak adlandırılan bir yöntem geliştirilmiştir (30). qRT-PCR yönteminde negatif ve pozitif kontrol eklenmesiyle, STR-PCR'a göre yöntemin doğruluğu, çalışması ve kontaminasyonu gibi testin hassasiyetini etkileyen risk faktörleri giderilmiştir.

Kantitatif kimerizm yönteminde real time metodu için TaqMan fluoresan tekniği kullanılmaktadır. TaqMan probunun genel özelliği 5'-3' uçlarında Haberci-5' (reporter) ve Susturucu-3' (quencher) denilen boyalar bulunmakta olup bu problar arasında ise hedef sekansa yönelik primer yer alır. Probun 5' ucunda FAM (6-karboksifluoresen), 3' ucunda ise TAMRA (6-karboksitetrametilrodamin) olarak adlandirilan floresanlar bulunur. Çoğu probda haberci-5' ucunda bir diğer fluoresan olan VIC ile birlikte iki boya kullanılmaktadır (31). Aequorea victoria'dan elde edilen VIC, yoğun yeşil fluoresan 1şıma yapmaktadır. Bu boyaların kullanılması testin hassasiyetini etkileyen en önemli unsurlarından biridir. Belli sıcaklıklarda ve döngülerde kurulan PCR sonrası real time cihazında problar arasında bulunan sekans bölgesi amplifiye olmaya başladıkça fluoresan ışıkları lazer ışığının etkisi ile soğurup ışımaya başlamaktadır. Bu ışıma şiddeti ile PCR, ilgili analiz yazılımında izlenebilir olmakta, aynı anda negatif ve pozitif kontrollerin takibi de yapılabilmektedir. Kullanılan yazılım aracılığıyla tam bir kantitatif değerlendirme yapılıp, STR-PCR yönteminden farklı olarak insan kaynaklı hesaplama hatalarının da önüne geçilebilmektedir.

Insersiyon ve delesyonlar (InDel) ile SNP'ler bu yöntemde belirteç olarak kullanılır (32-34). Belli bir baz pozisyonunda tek bir nükleotidin değişmesi olarak tanımlanan SNP, DNA replikasyonu sırasında oluşan hatalar sonucu meydana geldiği düşünülmektedir. Çeşitli hastalıklara yatkınlık, farmakogenetik araştırmalar, epidemiyolojik çalışmalar gibi birçok konuda SNP'lerden yararlanıldığı gibi kimerizm analizinde de ayırt edici özelliğinden yararlanılmaktadır. SNP belirteçlerinin kullanıldığ 1 qRT-PCR kimerizm analizi, STR-PCR yöntemine göre hassas olmasının yanında, relaps riski yüksek olan hastaların daha erken tespitinde oldukça avantajlıdır (35). Diğer yandan InDel belirteçlerin kullanıldığ 1 kantitatif real time metodu iyi karakterize edilmiş bir yöntem olduğu gösterilmiştir (36). Özellikle akut lösemili hastanın artan karışık kimerizm statüsünde olanlar için, relaps riskinin izlenmesinde ve önlenmesinde oldukça hassas ve kolay bir metot olduğu öne sürülmüştür (33).

\section{Dijital Droplet PGR}

En son geliştirilmiş teknolojilerden biri olarak kabul edilen dijital droplet-PCR (dd-PCR), konvansiyonel olarak bilinen PCR'dan oldukça farklı bir metoda sahiptir. Bu yöntem ile kullanılan az miktardaki DNA, sıvı fazdaki damlacıklara bölünerek ve kopyalarının amplifikasyonu ile tespiti sağlanmaktadır (37). dd-PCR metoduyla süper miks denilen ve sonrasında cihazda damlacıklara bölünen özel bir master miks ile hedef bölgelerin olduğu primer-prob birleşiminden oluşan belirteçler aracılığıyla gerçekleştirilir. Hedef bölgeye ait belirteç ve bir DNA molekülü PCR cihazında damlacıklara ayrılır. Bu damlacık pozitif damlacık olarak seçilir ve kantitatif değerlendirilmesi, pozitif damlacıklar üzerinden yapılır. Cihazdaki emülsiyon stabilize edici madde içeren damlacık oluşturma yağı ile dolu olan kanaldan damlacıklar sıra halinde geçerler ve bu sırada lazer ile aktive olan belirteçlerin rengine göre ayrımı yapar. $\mathrm{Bu}$ belirteçler qRT-PCR'da olduğu gibi yine VIC, FAM boyalarını içerir. Her bir plate'in kuyucuğundaki farklı belirteçlerin kullanmasıyla bu yöntemden oldukça hassas ve doğru sonuçlar elde edilmesi sağlanır. Yöntemin en önemli avantajının konsantrasyondaki hedef bölgelerin sayısı bilindiği için standart bir eğriye gerek duyulmaması olduğu belirtilmiştir (37). Yani ayrı ayrı pozitif ve negatif şekilde hedefe yönelik fluoresan şiddetinin sinyali ölçülmekte olup bu sinyalden pozitif olanlar "bir", negatif olanlar "sıfır" olacak şekilde ikili bir kod tekniği kullanılmaktadır. Veriler Poisson dağılımına göre hesaplanır, böylece DNA kopya sayıları doğrudan standart eğriye gerek kalmadan hesaplanabilmektedir.Bu yöntem ile STR-PCR ve qRT-PCR yöntemleri karşılaştırıldığında karışık kimerizm vakalarında erken nüksün tespiti ile AHKHT hastalarının sağ kalımını önemli oranda olumlu olarak etkileyebileceğini ve daha hızlı bir protokol ile bir adım önde olabileceğini öne süren çalışmalar mevcuttur (38, 39).

\section{Yeni Nesil Dizileme}

Son dönemde birçok araştırma ve rutin laboratuvarı, oldukça hassas sonuç veren Yeni Nesil Dizileme (NGS) yöntemini kullanmaktadırlar (40-42). Genel olarak NGS üç ana basamaktan oluşmaktadır: 1- Kütüphane oluşturma, 2- DNA parçalarının ayrı ayrı dizilemesi, 3- Dizilerin birleştirilmesi. $\mathrm{Bu}$ yöntemde genomik olan DNA parçalara ayrılır ve ardından denatürasyona uğrayan DNA'lara adaptör moleküllerin bulunduğu primerler bağlanır. Mikroskopi lamına benzeyen özel slaytlara adaptör protein bağlı DNA örnekleri eklenir ve cihazdaki amplifikasyon ardından klonal olarak örneklerin çoğalması, denatürasyon ardından kümelerin oluşması şeklinde bir protokol akışı vardır. Nükleotidlerin 3'OH uçları kimyasal olarak slayta bağlanmış ve kapanmış olduğundan zincir sonlanmasina neden olur ve reaksiyon sonlanır. Elde edilen tüm bilgiler bilgisayar ortamında uygun yazılım üzerinde biyoinformatik araçlar kullanılarak analiz edilir. Kimerizm analizi için de NGS yöntemi geliştirilmiş ve verimli sonuçlar elde edilmiştir $(43,44)$. Hatta SNP tabanlı geliştirilmiş olan NGS yönteminin karışık kimerizm tespiti zor olan minimal rezidüel hastalığın (MRH) tespitinde oldukça başarılı, hatta altın standart yönteme göre daha üstün olduğunu öne süren çalışmalar mevcuttur (44).

\section{TARTIŞMA}

Allojenik Hematopoetik Kan Kök Hücre Transplantasyonu sonrası kimerizm izlemi birçok yönden transplantasyon başarısı açısından oldukça önemlidir. Kimerizm izlemi, relapsa dönebilen veya karışık kimerizmin erken tespitini sağlayarak hızlı bir şekilde gerekli tedavi protokolünün oluşturulmasına yardımcı olabilmektedir. Özellikle artan karışık kimerizm vakaları için normal seyirli devam eden 
kimerizm izlemlerine göre daha sık aralıklarla oluşturulmuş bir ajanda ile kimerizm takip edilmektedir. S1k aralıklı artan karışık kimerizm izlemindeki amaç, seçilmiş olan tedavinin hastadaki yanıtını izlemek, doz ayarlarını iyileştirmek ve gerekli ise alternatif tedavi seçimlerini değerlendirmektir.

Kimerizm izleminde transplantasyon başarısını sağlamak ve devam ettirmek için en önemli unsurlar, yöntemin seçimi ve uygulama stratejisidir. Bunlardan multipleks STR-PCR altın standart yöntem olarak kabul edilmektedir $(45,46)$. Ancak periferal kandan alınan örneğin total lökosit DNA kullanılarak STR-PCR kimerizm sonucu analizlerinde sensitivitesinin yeterli olmadığını gösteren çalışmalar mevcuttur (46-48). Bir diğer dezavantajı ise semi-kantitatif bir yöntem olmasıdır. Karışık kimerizm gözlenmesi durumunda kullanılan yazılımdaki transplantasyon öncesi-sonrasına ait piklerin yorumlanıp manuel olarak hesaplaması zorunluluğu, insan kaynaklı hatalara sebep olabilmektedir (28). Bu dezavantajlı durumun ücretsiz olarak sunulan, R tabanlı bir program ile çözülebileceği ve kantitatif bir sonuç verebileceği öne sürülmüştür (29). Teknolojinin gelişmesi ile birlikte qRT-PCR yöntemi kimerizm izleminde kullanılmaya başlanmıştır. Özellikle MRH tespiti için, STR-PCR yöntemine göre daha hassas yöntemlere ihtiyaç duyulmaktadır. Periferal kandan elde edilen DNA ve TaqMan teknolojisi kullanılan yöntemle $\% 0,1$ oranında hasta hücresini tespit edebildiği gösterilmiştir (36). Bundan dolayı multipleks STR-PCR yanında qRT-PCR yöntemi kullanımının özellikle relapsa dönebilecek riskli AHKHT hastalarının karışık kimerizm tespitinde kullanımının avantajlı olabileceğini öne süren çalışmalar mevcuttur $(49,50)$. Erken relapsin tespiti ile hastaya uygulanacak tedavi seçeneklerinin erken başlatılması, transplantasyon başarısına ve dolayısıyla hasta sağ kalım üzerine etkili olabileceği düşünülmektedir (51). qRT-PCR ayrıca multipleks STR-PCR yöntemine göre sonuç verme süresi bakımından avantajlı durumdadır. STR-PCR ile ortalama iki ya da üç iş günü içerisinde sonuç verilebiliyorken qRT-PCR ile bu süreyi saatlere düşürmek mümkün kılınmaktadır. Yapılan testin ardından yazılımdan direkt olarak kantitatif değerlendirme alınmaktadır ve böylece hesaplama hatasının gerçekleşmesi engellenmektedir. Kimerizm haricinde birçok hastalık ve diyagnoz testleri için qRT-PCR yöntemi kullanılır ve bu testler için çok az miktarda DNA yeterli olmaktadır. Kimerizm için geliştirilmiş qRT-PCR metodunda bir hasta için en az altı kuyucuk kullanıldığından, STR-PCR ile karşılaştırıldığında daha fazla DNA örneğine ihtiyaç duyulmaktadır. Hastanın qRT-PCR ile kimerizm izlemi başka bir laboratuvara geçecek ise hastanın transplantasyon öncesi yeterli DNA's1 transfer edilen merkeze temin edilmelidir (52). Yine bu yöntemin yüksek hassasiyetine rağmen, tekrarlı testlerin yapılmasının gerekli olması, bir hasta için en az altı kuyucukta testin tekrar ediliyor olması kantitatif değer verme gücünü sınırlamaktadır (53). Son zamanlarda geliştirilen dd-PCR kimerizm yöntemi birçok açıdan umut vaat etmektedir. Binlerce miktarda çoğaltılmış PCR ürünü olan amplikonlar ve reaksiyona girmiş olan primer-probe çifti, cihazda her biri, bir damlacıkta bulunmak üzere ayrilırlar ve analiz bu damlacıklar üzerindeki ışıma ile yapılmaktadır. Flow sitometri ve real time metotlarının hibridi gibi şekillendirilmiş, geleneksel metotlardan oldukça farklı olan bu yöntemle tam bir kantitatif değerlendirme yapılabilmektedir (37). Bu yöntem ile qRT-PCR yöntemleri karşılaştırıldığında dikkat çekici şekilde daha hassas ve kolay olduğu gösterilmektedir (38). Yöntemin düşük DNA konsantrasyonunda çalışabilmesi, tekrarlanabilir ölçümler yapılıyor olabilmesi, testin uygulama kolaylığı, hızlı ve yine dijital bir platformdan sonuç verebilmesi dd-PCR yönteminin avantajlarının en önemli faktörleri arasında sayılabilir. Özellikle çok küçük konsantrasyonlarda DNA elde edilen lenfosit hücre alt gruplarının kimerizm izleminin hızlı, kolay ve STR-PCR ile korele sonuçlar verdiği gösterilmiş olan çalışmalar mevcuttur (39). Dizileme yöntemlerinin hızlı gelişimi ile birlikte kimerizm için yeni nesil dizileme yöntemi kullanılabilir hale gelmiştir (54). Biyoinformatik tabanlı bir sonuç vermesi, STR belirteçleri üzerinden izlemin yapılması NGS yönteminin avantajlarındandır. NGS yönteminde, qRT-PCR yöntemine göre çok az DNA örneğinde bile 100 kattan fazla veri elde edilebilmektedir. Pettersson ve arkadaşları, geliştirmiş olduğu NGS tabanlı kimerizm yöntemiyle, STR-PCR ve qRT-PCR'ın birlikte kullanıldığı kimerizm izleme stratejisinin yerine geçebileceği, MRH'de lenfosit hücre alt grupları kimerizm izlemi için de kullanılabileceğini ileri sürmektedirler (43). Ayrıca MRH tespitinde SNP-NGS yönteminin, STR-PCR'a göre daha üstün olduğunu bildiren çalışmalar mevcuttur (44). Her ne kadar diğer moleküler kimerizm metotlarına göre daha kesin ve hassas sonuç verse de, analizinin ve test protokolünün uzunluğu ve kompleks yapıs1, maliyetinin yüksekliği ve yöntemin uygulanabilirliği, NGS kimerizm yönteminin önünde aşılması gereken engellerin arasında yer almaktadır.

\section{SONUÇ}

Allojenik hematopoetik kök hücre transplantasyonu sonrası kimerizm izlemi transplantasyon başarısında önemli bir yer almaktadır. Moleküler kimerizm yöntemlerin gelişmesi ile yıllar içinde PCR tekniğinin çeşitli modifikasyonlarıyla farklı seçenekler ve oldukça hassas yöntemler geliştirilmiştir. Son yıllarda ise kanser taramasından, genom araştırmalarına, transplantasyon öncesi "insan lökosit antijen" uyumundan, birçok araştırma alanında kullanılabilen yeni nesil dizileme yöntemi de kimerizm izlemi için modifiye edilmiş ve oldukça başarılı sonuçlar açıklanmıştır. Bu derlemede altın standart olan STR-PCR kimerizm yöntemine alternatif yöntemler avantajları ve dezavantajları ile birlikte açıklanmıştır. Transplantasyon sonrası kimerizm izleminde hangi yöntemin seçileceği ve hangi sıklıklarla uygulanacağı hastalığın türüne, relaps riskine, transplantasyon hekiminin takip stratejisine, takip laboratuvarının sahip olduğu altyapı ve koşullarına bağlı olmaktadır. Ancak günümüzde geliştirilen kimerizm yöntemleri değerlendirildiğinde, çok daha az miktarda DNA'nın hassas ve kantitatif sonuçlar verdiği alternatif yöntemler, geleneksel olan altın standart yöntemin yerini alabileceği yönündedir.

Çıkar Çatışması: Yazarların beyan edecek bir çıkar çatışması yoktur.

Finansal Destek: Yazarlar bu çalışma için finansal destek almadıklarını beyan etmişlerdir. 


\section{KAYNAKLAR}

1. Schmitt M. Bellerophon and the Chimaera in Archaic Greek Art. American Journal of Archaeology 1966; 70(4):341-7.

2. Anderson D, Billingham RE, Lampkin GH, Medawar PB. The use of skin grafting to distinguish between monozygotic and dizygotic twins in cattle. Heredity 1951; 5:379-97.

3. Bianchi DW, Zickwolf GK, Weil GJ, Sylvester S, DeMaria MA. Male fetal progenitor cells persist in maternal blood for as long as 27 years postpartum. Proc Natl Acad Sci U S A. 1996; 93(2):705-8.

4. Boklage CE. Embryogenesis of chimeras, twins and anterior midline asymmetries. Hum Reprod 2006; 21(3):579-91.

5. Koopmans M, Kremer Hovinga IC, Baelde HJ, Fernandes RJ, de Heer E, Bruijn JA, Bajema IM. Chimerism in kidneys, livers and hearts of normal women: implications for transplantation studies. Am J Transplant 2005; 5(6):1495-502.

6. Yu N, Kruskall MS, Yunis JJ, Knoll JH, Uhl L, Alosco S, Ohashi M, Clavijo O, Husain Z, Yunis EJ, Yunis JJ, Yunis EJ. Disputed maternity leading to identification of tetragametic chimerism. N Engl J Med 2002; 346(20):1545-52.

7. Novotný J, Lotz P, Müller S, Steinlein O. Identification of tetragametic human chimerism by routine DNA profiling. Int J Legal Med 2019; 133(4):989-92.

8. Verdiani S, Bonsignore A, Casarino L, Ferrari GM, Zia SC, De Stefano F. An unusual observation of tetragametic chimerism: forensic aspects. Int J Legal Med 2009; 123(5):431-5.

9. Crouse CA, Schumm J. Investigation of species specificity using nine PCR-based human STR systems. J Forensic Sci 1995; 40(6):952-6.

10. Manasatienkij C, Ra-ngabpai C. Clinical application of forensic DNA analysis: a literature review. J Med Assoc Thai 2012; 95(10):1357-63.

11. Walseng E, Köksal H, Sektioglu IM, Fane A, Skorstad G, Kvalheim G, Gaudernack G, Inderberg EM, Walchli S. TCR-based chimeric antigen receptor. Sci Rep 2017; $7: 10713$.

12. Rautenberg C, Germing U, Haas R, Kobbe G, Schroeder T. Relapse of acute myeloid leukemia after allogeneic stem cell transplantation: Prevention, detection, and treatment. Int J Mol Sci 2019; 20(1):228.
13. Quader M, Toldo S, Chen Q, Hundley G, Kasirajan V. Heart transplantation from donation after circulatory death donors: Present and future. J Card Surg 2020; 35(4):875-85.

14. Augustine J. Kidney transplant: New opportunities and challenges. Cleve Clin J Med 2018; 85(2):138-44.

15. Bloch EM, Jackman RP, Lee TH, Busch MP. Transfusion-associated microchimerism: the hybrid within. Transfus Med Rev 2013; 27(1):10-20.

16. Ma KK, Petroff MG, Coscia LA, Armenti VT, Adams Waldorf KM. Complex chimerism: pregnancy after solid organ transplantation. Chimerism 2013; 4(3):71-7.

17. Trivedi HL, Vanikar AV, Modi PR, Shah VR, Vakil JM, Trivedi VB, Khemchandani SI. Allogeneic hematopoietic stem-cell transplantation, mixed chimerism, and tolerance in living related donor renal allograft recipients. Transplant Proc 2005; 37(2):737-42.

18. Bader P, Kreyenberg H, Hoelle W, Dueckers G, Handgretinger R, Lang P, Kremens B, Dilloo D, Sykora KW, Schrappe M, Niemeyer C, Von Stackelberg A, Gruhn B, Henze G, Greil J, Niethammer D, Dietz K, Beck JF, Klingebiel T. Increasing mixed chimerism is an important prognostic factor for unfavorable outcome in children with acute lymphoblastic leukemia after allogeneic stem-cell transplantation: possible role for pre-emptive immunotherapy? J Clin Oncol 2004; 22(9):1696-705.

19. Rettinger E, Willasch AM, Kreyenberg H, Borkhardt A, Holter W, Kremens B, Strahm B, Woessmann W, Mauz-Koerholz C, Gruhn B, Burdach S, Albert MH, Schlegel PG, Klingebiel T, Bader P. Preemptive immunotherapy in childhood acute myeloid leukemia for patients showing evidence of mixed chimerism after allogeneic stem cell transplantation. Blood 2011; 118(20):5681-8.

20. Guz K, Nasilowska B, Tomaszewska A, Orzinska A, Smolarczyk-Wodzynska J, Krzemienowska M, Halaburda K, Przybylski M, Jedrzejczak WW, Marianska B, Brojer E. Real-time PCR analysis of chimerism in T cell subsets as an early predictor of Graft-versus-host-disease following allogeneic stem cell transplantation. Ann Transplant 2015; 20:720-8.

21. Stumph J, Vnencak-Jones C, Koyama T, Frangoul H. Comparison of peripheral blood and bone marrow samples for detection of post transplant mixed chimerism. Bone Marrow Transplant 2008; 41:589-590.

22. Bach C, Steffen M, Roesler W, Winkler J, Mackensen A, Stachel KD, Metzler M, Spriewald BM. Systematic comparison of donor chimerism in peripheral blood and 
Abatay Sel F. ve Savran Oğuz F.

bone marrow after hematopoietic stem cell transplantation. Blood Cancer J 2017; 7(6):e566.

23. Botstein D, White RL, Skolnick M, Davis RW. Construction of a genetic linkage map in man using restriction fragment length polymorphisms. Am J of Hum Genet 1980; 32(3):314-31.

24. Dumbovic G, Forcales SV, Perucho M. Emerging roles of macrosatellite repeats in genome organization and disease development. Epigenetics 2017; 12(7):515-26.

25. Trent RJ. Genes to personalized medicine. In: Trent RJ. Molecular Medicine: genomics to personalized healthcare. 4th Ed. San Diego, CA, USA, Academic Press 2012: 1-37.

26. Dumache R, Enache A, Barbarii L, Costantinescu C, Pascalau A, Jinca C, Arghirescu S. Chimerism monitoring by short tandem repeat (STR) markers in allogeneic stem cell transplantation. Clin Lab 2018; 64:1535-43.

27. Lawler M, McCann SR, Conneally E, Humphries P. Chimerism following allogeneic bone marrow transplantation: Detection of residual host cells using the polymerase chain reaction. $\mathrm{Br} \mathrm{J}$ Haematol 1989; 73(2):205-10.

28. Thiede C, Florek M, Bornhäuser M, Ritter M, Mohr B, Brendel C, Ehninger G, Neubauer A. Rapid quantification of mixed chimerism using multiplex amplification of short tandem repeat markers and fluorescence detection. Bone Marrow Transplant 1999; 23(10):1055-60.

29. Siddiqui Z, Maldonado J, Grojean J, Ye F, Zhang D, Longtine J, Ahn TH, Guo H. Rchimerism: An R package for automated chimerism data analysis. J Mol Diagn 2020; 22(1):21-9.

30. Hagen-Mann K, Mann W. RT-PCR and alternative methods to PCR for in vitro amplification of nucleic acids. Exp Clin Endocrinol Diabetes 1995; 103(3):150-5.

Butler JM. DNA Quantitation. In: John M. Butler.

31. Advanced Topics in Forensic DNA Typing: Methodology. 1st Ed. Maryland, USA: Academic Press 2012: 49-67.

32. Cheranev VV, Loginova MA, Kutyavina SS, Smirnova DN, Zorina NA, Minaeva NV, Paramonov IV. [Expirience introduction of quantitative analysis of chimerism after allogenic stem cell transplantation by real-time PCR with InDel polymorphism.]. Klin Lab Diagn 2019; 64(12):762-8.

33. Jacque N, Nguyen S, Golmard JL, Uzunov M, Garnier A, Leblond V, Vernant JP, Bories D, Dhédin N. Chimerism analysis in peripheral blood using indel quantitative real-time PCR is a useful tool to predict post-transplant relapse in acute leukemia. Bone Marrow Transplant 2015; 50(2):259-65.

34. Almeida CA, Dreyfuss JL, Azevedo-Shimmoto MM, Figueiredo MS, de Oliveira JS. Evaluation of 16 SNPs allele-specific to quantify post hSCT chimerism by SYBR green-based qRT-PCR. J Clin Pathol 2013; 66(3):238-42.

35. Elmaagacli AH. Real-time PCR for monitoring minimal residual disease and chimerism in patients after allogeneic transplantation. Int J Hematol 2002; 76 Suppl 2:204-05.

36. Alizadeh M, Bernard M, Danic B, Dauriac C, Birebent B, Lapart C, Lamy T, Le Prise PY, Beauplet A, Bories D, Semena G, Quelvennec E. Quantitative assessment of hematopoietic chimerism after bone marrow transplantation by real-time quantitative polymerase chain reaction. Blood 2002; 99:4618-25.

37. Huggett JF, Cowen S, Foy CA. Considerations for digital PCR as an accurate molecular diagnostic tool. Clin Chem 2015; 61(1):79-88.

38. Valero-Garcia J, Gonzalez-Espinosa MdC, Barrios M, Carmona-Antonanzas G, Garcia-Planells J, Ruiz-Lafora C, Fuentes-Galvez A, Jimenez-Velasco A. Earlier relapse detection after allogeneic haematopoietic stem cell transplantation by chimerism assays: Digital PCR versus quantitative real-time $\mathrm{PCR}$ of insertion/deletion polymorphisms. PLoS One 2019; 14(2): e0212708.

39. Mika T, Baraniskin A, Ladigan S, Wulf G, Dierks S, Haase D, Schork K, Turewicz M, Eisenacher M, Schmiegel W, Schroers R, Klein-Scory S. Digital droplet PCR-based chimerism analysis for monitoring of hematopoietic engraftment after allogeneic stem cell transplantation. Int J Lab Hematol 2019; 41(5):615-21.

40. Pettersson L, Vezzi F, Vonlanthen S, Alwegren K, Hedrum A, Hauzenberger D. Development and performance of a next generation sequencing (NGS) assay for monitoring of mixed chimerism. Clin Chim Acta 2021; 512:40-8.

41. Sunami K, Ichikawa H, Kubo T, Kato M, Fujiwara Y, Shimomura A, Koyama T, Kakishima H, Kitami M, Matsushita H, Furukawa E, Narushima D, Nagai M, Taniguchi H, Motoi N, Sekine S, Maeshima A, Mori T, Watanabe R, Yoshida M, Yoshida A, Yoshida H, Satomi K, Sukeda A, Hashimoto T, Shimizu T, Iwasa S, Yonemori K, Kato K, Morizane C, Ogawa C, Tanabe N, Sugano K, Hiraoka N, Tamura K, Yoshida T, Fujiwara Y, Ochiai A, Yamamoto N, Kohno T. Feasibility and utility 
of a panel testing for 114 cancer-associated genes in a clinical setting: A hospital-based study. Cancer Sci 2019; 110(4):1480-90.

42. Chen M, Zhao H. Next-generation sequencing in liquid biopsy: cancer screening and early detection. Hum Genomics 2019; 13(1):34.

43. Pettersson L, Vezzi F, Vonlanthen S, Alwegren K, Hedrum A, Hauzenberger D. Development and performance of a next generation sequencing (NGS) assay for monitoring of mixed chimerism. Clin Chim Acta 2020; 512:40-48.

44. Lee JM, Kim YJ, Park SS, Han E, Kim M, Kim Y. Simultaneous monitoring of mutation and chimerism using Next-Generation Sequencing in Myelodysplastic Syndrome. J Clin Med 2019; 8(12):2077.

45. Clark JR, Scott SD, Jack AL, Lee H, Mason J, Carter GI, Pearce L, Jackson T, Clouston H, Sproul A, Keen L, Molloy K, Folarin N, Whitby L, Snowden JA, Reilly JT, Barnett D. United Kingdom National External Quality Assessment Service for Leucocyte Immunophenotyping Chimerism Working Group. Monitoring of chimerism following allogeneic haematopoietic stem cell transplantation (HSCT): technical recommendations for the use of short tandem repeat (STR) based techniques, on behalf of the United Kingdom National External Quality Assessment Service for Leucocyte Immunophenotyping Chimerism Working Group. Br J Haematol 2015; 168(1):26-37.

46. Lion T, Watzinger F, Preuner S, Kreyenberg H, Tilanus M, de Weger R, van Loon J, de Vries L, Cave H, Acquaviva C, Lawler M, Crampe M, Serra A, Saglio B, Colnaghi F, Biondi A, van Dongen JJM, van der Burg M, Gonzalez M, Alcoceba M, Barbany G, Hermanson M, Roosnek E, Steward C, Harvey J, Frommlet F, Bader P. The EuroChimerism concept for a standardized approach to chimerism analysis after allogeneic stem cell transplantation. Leukemia 2012; 26:1821-8.

47. Schraml E, Daxberger H, Watzinger F, Lion T. Quantitative analysis of chimerism after allogeneic stem cell transplantation by PCR amplification of microsatellite markers and capillary electrophoresis with fluorescence detection: the Vienna experience. Leukemia 2003; $17: 224-7$.

48. Kreyenberg H, HölleW, Möhrle S, Niethammer D, Bader P.Quantitative analysis of chimerism after allogeneic stem cell transplantation by PCR amplification of microsatellite markers and capillary electrophoresis with fluorescence detection: the Tuebingen experience. Leukemia 2003; 17:237-40.
49. Abatay-Sel F, Savran-Oguz F, Kalayoglu-Besisik S, Mastanzade M, Duvarci-Ogret Y, Yonal-Hindilerden I, Aydin F. Short tandem repeat-polymerase chain reaction (STR-PCR) with quantitative real time-polymerase chain reaction (qRT-PCR) method using for chimerism analysis. Clin Lab 2019; 65(9):1697-703.

50. Tyler J, Kumer L, Fisher C, Casey H, Shike H. Personalized chimerism test that uses selection of short tandem repeat or quantitative PCR depending on patient's chimerism status. J Mol Diagn 2019; 21: 483-90.

51. Kliman D, Nivison-Smith I, Gottlieb D, Hamad N, Kerridge I, Purtill D, Szer J, Ma D. Hematopoietic stem cell transplant recipients surviving at least 2 years from transplant have survival rates approaching population levels in the modern era of transplantation. Biol Blood Marrow Transplant 2020; 26(9):1711-8.

52. Navarro-Bailon A, Carbonell D, Escudero A, Chicano M, Muniz P, Suarez-Gonzales J, Bailen R, Oarbeascoa G, Kwon M, Diez-Marin JL, Martinez-Laperche C, Buno I. Short tandem repeats (STRs) as biomarkers fort he quantitative follow-up of chimerism after stem cell transplantation: Methodological consideritions and clinical application. Genes 2020; 11(9):993.

53. Thiede C, Bornhauser M, Ehninger G. Strategies and clinical implications of chimerism diagnostics after allogeneic hematopoietic stem cell transplantation. Acta Haematol 2004; 112:16-23.

54. Aloisio M, Licastro D, Caenazzo L, Torboli V, D'Eustacchio A, Severini GM, Athanasakis E. A technical application of quantitative next generation sequencing for chimerism evaluation. Mol Med Rep 2016; 14:2967-74. 